\title{
溶解拡散型 $\mathrm{CO}_{2}$ 海洋隔離における希釈放流技術に関する 基礎研究（その 2)
}

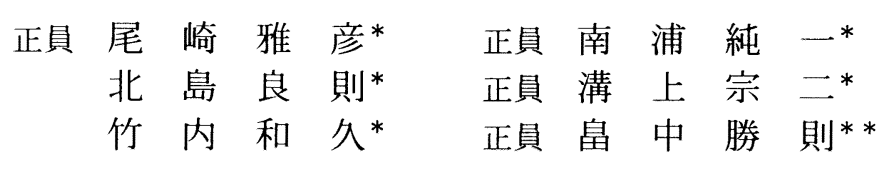

Technical Feasibility of $\mathrm{CO}_{2}$ Injection and Dilution into Ocean Depths for Dissolution Type of Ocean Sequestration of $\mathrm{CO}_{2}$ (second report)

by Masahiko Ozaki, Member

Yoshinori Kitajima

Kazuhisa Takeuchi

\begin{abstract}
Summary
Ocean sequestration of the captured $\mathrm{CO}_{2}$ from fossil fuel burning is a possible option to mitigate the increase of $\mathrm{CO}_{2}$ concentration in the atmosphere. Moving ship type of $\mathrm{CO}_{2}$ ocean sequestration is treated in this study. That is, liquefied $\mathrm{CO}_{2}$ is delivered by ship to the site and injected into ocean depths of 1,000 to $2.500 \mathrm{~m}$ with a suspended and towed pipe by a slowly moving ship. In addition to the horizontal movement of releasing point, use of the rising journey of $\mathrm{CO}_{2}$ droplets till they disappear by dissolution is effective for the dilution of $\mathrm{CO}_{2}$ in seawater. The distance between the released depth of $\mathrm{CO}_{2}$ and the disappearing depth depends on the initial size of droplets, the dissolution rate and the rising velocity. The possibility of generating relatively large size of droplets from moving nozzle was investigated in the previous report. In this report, the terminal velocity of $\mathrm{CO}_{2}$ droplet under the deep-sea circumstances is measured in a large high-pressure tank, considering the influence of the hydrate film on droplet and the possible deformation when its size is relatively large. And the rising and dissolving behavior of $\mathrm{CO}_{2}$ droplet is calculated to estimate the rising journey of $\mathrm{CO}_{2}$ droplets in the scenario of the moving ship type of $\mathrm{CO}_{2}$ ocean sequestration.
\end{abstract}

\section{1. 緒}

大気中への $\mathrm{CO}_{2}$ 排泪抑制の一方策として、燃娔排ガスか ら分離回収した $\mathrm{CO}_{2}$ を海洋へ送り込み長期にわたって大気

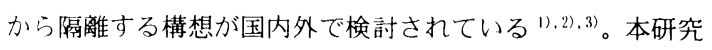
では、溶解㹡散型の $\mathrm{CO}_{2}$ 海洋隔離として、海洋の自然の混 合に委衫る前に人為的に一定以上の希釈度を確保する技術 的方策；航走船舶（Moving ship）による中層希釈放流方式

\footnotetext{
* 三菱重工業 (株) 長崎研究所. RITE 長崎分室

** 長菱エンジニアリング (株)
}

原稿受理 平成 12 年 7 月 10 日

秋季講演会に扔いて講演 斗成 12 年 11 月 16,17 日
(Fig. 1）を提案している。前報け)では、放虬した $\mathrm{CO}_{2}$ を短 時間のうちに周辺海水に溶かし込んで $\mathrm{CO}_{2}$ 濃度の不均一を 解消する「急速溶解による希釈」と、 $\mathrm{CO}_{2}$ 液滴をある程度大 きく生成させ液滴が溶けきるまでの浮上距離を鈶直方向の 希釈に利用する「低速溶解による希釈」の二通りの考え方が あることを示した。両者のどちらが影響の少なさや復元の可 能性で優位であるかは現時点で明らかでないが、技術的な見 通しを得るために、特に「低速溶解による希釈」で必要とな る $\mathrm{CO}_{2}$ 液滴の初期挙動に関する基礎研究を行った。

曳航パイプの下端部近傍に設けられる多数の小孔あるい はノズルから液化 $\mathrm{CO}_{2}$ を放流する場合、ノズル出口におい て周囲流体によって $\mathrm{CO}_{2}$ 液滴は形成途中で引きちぎられ、 さらにパイプ背後に生起される渦流によって分裂して、微細 化することが、模擬流体を用いた史航水槽実験により判明し た。そこで、各ノズルを渦流の影響のないところに配置する とともに、軸線が曳航方向に沿う流線形の水平曳航体とし、 


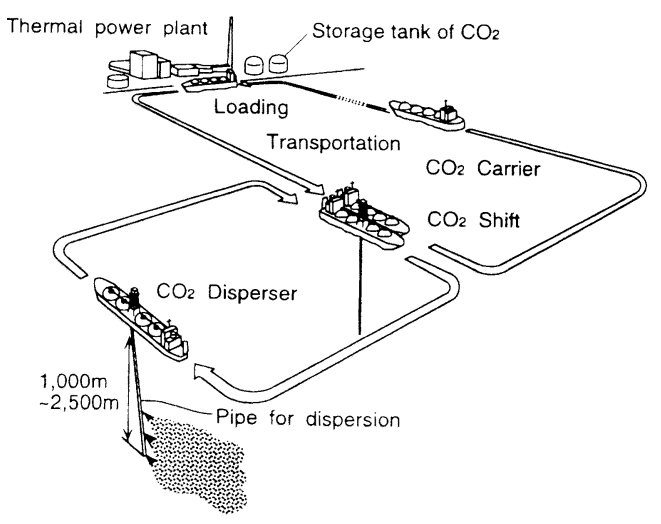

Fig.1 Conceptual view of $\mathrm{CO}_{2}$ dispersion in ocean depths by moving ship

放川速度を調整して後乃向きに放流することによって、現実 的な史航速度（4〜 5 ノット）の下で一定以上（值径 $10 \mathrm{~mm}$ 以

上）の液滴形成が可能であるとの見通しを得た。

本報では、深海の低温・高圧状態を再現した大型高圧容器 内の海水中に、液化 $\mathrm{CO}_{2}$ を放㸝する実験を行い、液滴の浮 上形態の観察、ならびに上昇速度デー夕の取得を行う。また、 そのデータにもとづき、上昇しながら周囲の海水に溶けてい く液滴の挙動をシミュレーション計算で予測し、実機想定の 100 リットル毎秒の規模の放流においても高い初期希釈率 が得られることを示す。

\section{2. 大型高压容器内 $\mathrm{CO}_{2}$ 放出実旿}

\section{1 必要性}

深度 1, 000 2, 500m 程度の深海の海水中に液化 $\mathrm{CO}_{2}$ を送 り込む希釈放流方式において、放流点周辺域の睘境影響予測 を行うために、放流後の $\mathrm{CO}_{2}$ の分散・浮上・溶解・抎散を ともなう挙動を推定する必要がある。この予測のためには、 初期条件となる放流直後の $\mathrm{CO}_{2}$ 液滴の状態を明確にする必 要があるが、液滴状態は周辺海水の条件や $\mathrm{CO}_{2}$ 放蜊条件に より変わるので、できるだけ現実に近い条件の下でデー夕を 蓄積するよう、次の点に留意が必要である。

1) $\mathrm{CO}_{2}$ は常温・常圧下において気体であり、低温にするだ けでは気相から固相へ移るだけである。深海の高圧下に おける液滴としての挙動を直接調べるためには、高圧実 験装置を導入するか実際に深海の場で実験を行う必要 がある。

2）深海の温度・圧力条件下では、海水と $\mathrm{CO}$. の界面に八 イドレート膜（固体の薄膜）が生成されるので、特有な 現象として考慮に入れる必要がある。ハイドレートの物 性データは整備されはじめたばかりである。
3）基礎データの収集には、実験条件の設定が容易でかつ再 現できることが望まれる。

以上を勘案し、深海の低温・高圧状態を再現した大型高圧容 器内の海水中に液化 $\mathrm{CO}_{2}$ を放蜊する実験を実施して $\mathrm{CO}_{2}$ の 浮上挙動を観察し、上昇速度に関するデー夕を取得する。

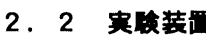

実験は、大型高圧容器内に、CO2 容器および放忛装置、な らびに計測装置を入れて、低温海水充填後、所定の圧力まで 加圧し、遠隔㨐作で $\mathrm{CO}_{2}$ 放帅を行って観察と計测を行う。 実験のシステム全体の概念図をFig. 2 に、装置の設置状況の 写真をFig. 3 にそれぞれ示す。

\section{2 . 1 大型高圧容器}

実験に利用した大型高压容器は、米国テキサス州サンアン トニオ市の研究機関 Southwest Research Institute(SwRI) が保有するものの一つで、以下のような仕様である。

· 縦型円筒圧力容器

- 上蓋着脱式

・内径 $2,280 \mathrm{~mm}$ 、深さ $5,840 \mathrm{~mm}$

・ 容積約 $23 \mathrm{~m}^{3}$

- 耐圧 $28 \mathrm{MPa}$ (深度 $2.700 \mathrm{~m}$ に相当)

\section{2. $2.2 \mathrm{CO}_{2}$ 容器}

$\mathrm{CO}_{2}$ 容器はFig. 4 のような、低温用ゴム製の袋状隔膜(ブ ラダ) をステンレス製の外殼の内側に装着したもので、装備 段階の $\mathrm{CO}_{2}$ 充填時の内压（6.5 MPa）に耐え、大型高压容器 の加圧時には均圧弁が開いて袋状隔膜の内外圧が均衡する ようになっている。充填可能な $\mathrm{CO}_{2}$ は $5.1 \mathrm{~kg}$ であるが、実 験時の使用可能量は約 $3.5 \mathrm{~kg}$ である。

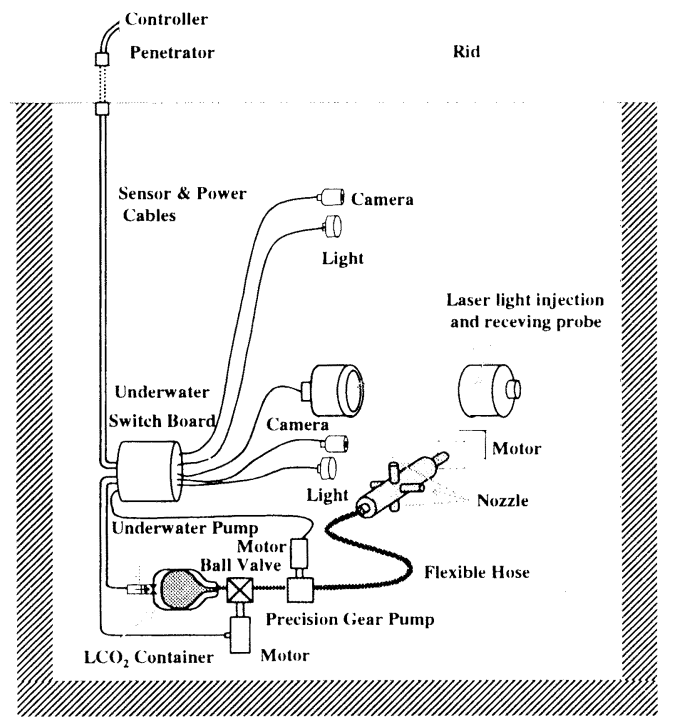

Fig.2 Arrangement of test apparatus in high pressure vessel 

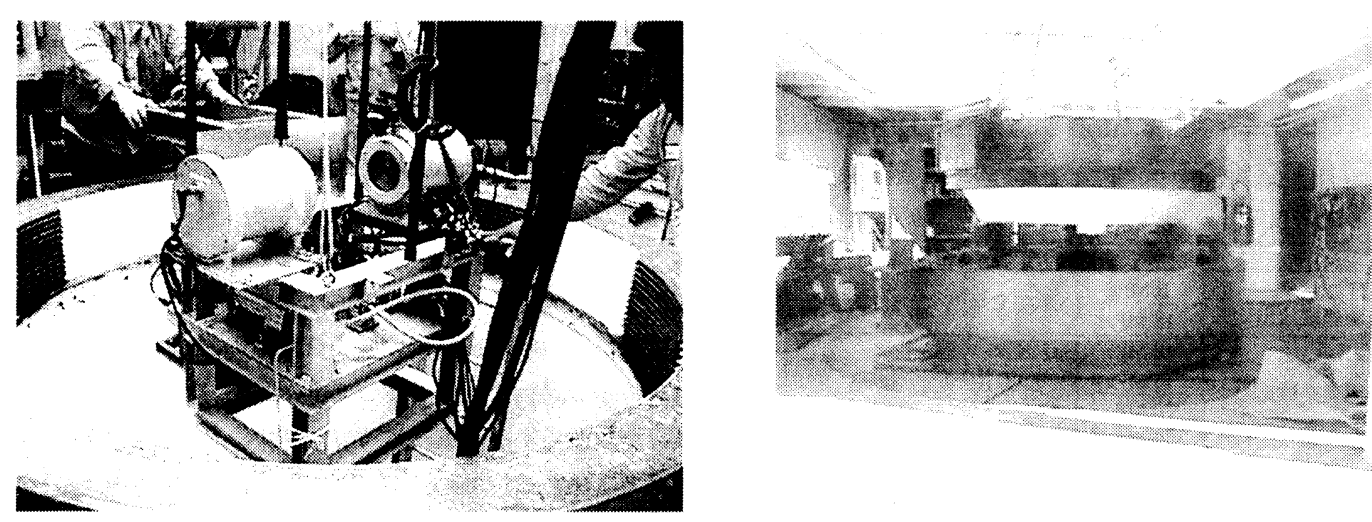

Fig.3 Setting of test apparatus in high pressure vessel

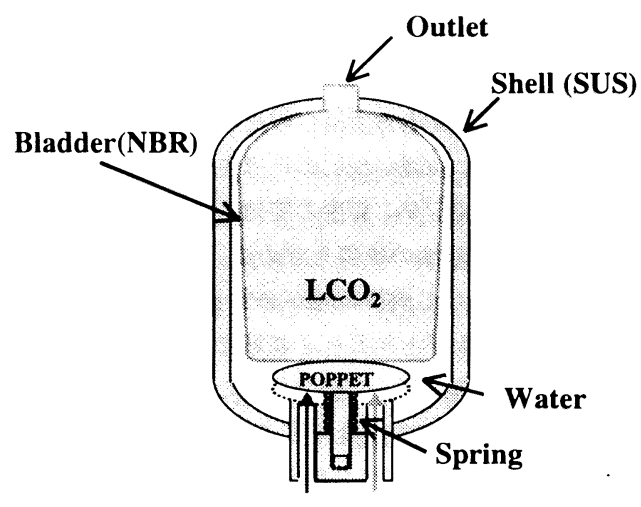

Fig.4 Container of liquid $\mathrm{CO}_{2}$

\section{2.3 放出装是}

$\mathrm{CO}_{2}$ 容器内の液化 $\mathrm{CO}_{2}$ を遠隔操作によって流量を制御し ながら放出する装置は、開閉用ボールバルブ、同作動用モー 夕、定流量ポンプ、ノズル装置および配管・制御系から構成 される。定流量ポンプはギアポンプであり、回転数を操作 することによって $0 \sim 10 \mathrm{cc} / \mathrm{sec}$ の範囲で流量を制御するこ とができる。ノズル装置は㨁径 $60 \mathrm{~mm} の \mathrm{CO}_{2}$ 放出管に 90 度 間隔で放射状に 4 個のノズル（内径 $3 \sim 15 \mathrm{~mm}$ ）を設け、遠隔 操作で $\mathrm{CO}_{2}$ 放出管を回転させてノズル変更を行うことが可 能である。放出管・ノズルともにステンレス製である。

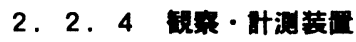

$\mathrm{CO}_{2}$ 液滴の挙動を钼察するために、放出ノズル近傍ならび に約 $2.400 \mathrm{~mm}$ 上方を水中カメラで撮影した。無色透明の $\mathrm{CO}_{2}$ 液滴を可視化するため、アルミ平板をカメラの対向位置に設 置するとともに、水中ランプ（光量調節可能）を被写体の横 から照らすように配置した。

上昇時に必ずしも真上に浮上するとは限らない液滴の大 きさを、カメラ映像から正確に測定することは難しいと考え られる。そこで、放出ノズルの約 $300 \mathrm{~mm}$ 上方にレーザ式粒径
計測装置を設置した。本装置は工業用に市販されているもの を応用したものである。本来の機能としては、回転ミラーと コリメータレンズを使って、レーザビームを同一平面内で平 行、高速かつ一定速度でスキャンする。ビームは受光レンズ で集光され、受光素子で電気信号に変換される。その強度は 投光器と受光器の間に物体が存在しないときに最大で一定 である。スキャン域内に不透明な物体があるとビームが遮ら れ、ある時間、強度が低下するので、その時間間隔により外 径を算出する、というものである。本実験の対象は無色透明 物体であり、屈折率の違いによって、ビームが物体の端部を 通過する時にのみ強度が低下するので、スキャンした波形の 変化を解析して外径を算出するように機能追加を行った。ガ ラス玉を対象にした事前性能試験で誤差は $0.1 \mathrm{~mm}$ 以下であ ることが確認されている。スキャン方向を水平にし、サンプ リング時間間隔を 0.01 秒に設定した。 $10 \mathrm{~cm} / \mathrm{sec}$ で上昇する 直径 $10 \mathrm{~mm}$ の液滴は約 10 回スキャンされることになるので、 液滴の赤道部の值 (水平方向直径) をとらえることが可能で あると考えられる。

以上のほか、大型高圧容器に付属している圧力センサで容 器内圧力を、熱電対 4 基で海水温度の鈶直分布をモニタした。

\section{2 . 5 低温海水}

大型高圧容器内の海水は、化学的に厳密なものではない。 塩分濃度 $3 \sim 3.5 \%$ 、水温 $2 \sim 5$ 度 C を目標とし、水道水をべ 一スに、密度を調整するための塩と、温度を調整するための 水を混ぜ、擋汼・滤過を行ったものである。実験に供する前 に比重瓶で密度計測を行った。

\section{3 实 故}

\section{3. 1 实臨の活類・条件}

実験は平成 10 年 (1998 年) 12 月に、下記の順で行われた。

・常温高圧海水中 $\mathrm{CO}_{2}$ 液滴連続放出実験

・低温高圧海水中 $\mathrm{CO}_{2}$ 液滴連続放出実験

・低温高圧海水中 $\mathrm{CO}_{2}$ 液滴単体放出実験 
実験時の大型高圧容器内海水の温度 - 密度 (大気圧下) およ び圧力条件は、Table 1 に示すとおりである。

\section{Table 1 実験条件}

\begin{tabular}{|c|c|c|c|}
\hline & 水 压 & 水 温 & 密度(大気压下) \\
\hline \multirow{2}{*}{$\begin{array}{l}\text { 常温高压海水中 } \\
\mathrm{CO}_{2} \text { 液滴連続放出 }\end{array}$} & $10 \mathrm{MPa}$ & \multirow{2}{*}{$17.2^{\circ} \mathrm{C}$} & \multirow{2}{*}{1.028} \\
\hline & $15 \mathrm{MPa}$ & & \\
\hline \multirow{3}{*}{$\begin{array}{l}\text { 低温高圧海水中 } \\
\mathrm{CO}_{2} \text { 液滴連続放出 }\end{array}$} & $10 \mathrm{MPa}$ & \multirow{3}{*}{$3.9^{\circ} \mathrm{C}$} & \multirow{3}{*}{1.031} \\
\hline & $15 \mathrm{MPa}$ & & \\
\hline & $20 \mathrm{MPa}$ & & \\
\hline \multirow{5}{*}{$\begin{array}{l}\text { 低温高圧海水中 } \\
\mathrm{CO}_{2} \text { 液滴単体放出 }\end{array}$} & $10 \mathrm{MPa}$ & $2.2^{\circ} \mathrm{C}$ & \multirow{5}{*}{1.026} \\
\hline & $15 \mathrm{MPa}$ & $2.2^{\circ} \mathrm{C}$ & \\
\hline & $20 \mathrm{MPa}$ & $1.7^{\circ} \mathrm{C}$ & \\
\hline & $15 \mathrm{MPa}$ & $5.1)^{\circ} \mathrm{C}$ & \\
\hline & $20 \mathrm{MPa}$ & $5.0^{\circ} \mathrm{C}$ & \\
\hline
\end{tabular}

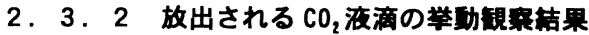

(1) 常温高圧海水中 $\mathrm{CO}_{2}$ 液滴連続放出実験

ハイドレート生成のために必要な温度条件は約 10 度 C 以 下である。したがって常温における放出実験は、ハイドレー 卜生成に起因する装置の不具合の可能性を除外しての、装置 作動確認を兼ねたものである。 $\mathrm{CO}_{2}$ の放壮流量が $10 \mathrm{cc} / \mathrm{sec}$ 以下と小さいために、液滴はすべてノズル先端から間欠的に 分離して浮上した。予想のとおり、放出された $\mathrm{CO}_{2}$ 液滴に ハイドレート膜は生成しない。浮上時の液滴には周期的変形 や上昇経路の蛇行が見られる。断続的に形成される液滴の大 きさはほぼ一定であるが、液滴同士の上下間隔は均一でなく、 2 個ごとに組になって近づいたり離れたりしながら浮上し ていくようであった。液化 $\mathrm{CO}_{2}$ の密度は温度・圧力に対す る依存度が高く、常温では海水と $\mathrm{CO}_{2}$ の密度差が低温の時 よりも大きくて余剩浮力が大きいため、液滴上昇速度は後述 する実験の時よりも大きかった。

\section{（2）低温高圧海水中 $\mathrm{CO}_{2}$ 液滴連続放出実験}

低温になると液滴には八イドレート膜が生成した。ただし、 ノズルから分離した直後では、ハイドレート膜が生成する場 合と生成しない場合とが混在して見られた。しかしノズルか ら $2.4 \mathrm{~m}$ 上方のカメラの映像ではすべての液滴がハイドレー ト膜で栄われていた。実験の時間経過とともにノズルは八イ ドレートで閉塞する傾向にあり、内径が小さいほど短時間で 使用不能となった。最も内径の大きなノズルでは、ハイドレ 一トがノズル開口部を中央付近で二分するように生成した 場合があり、並行して二つの夜滴が成長しほぼ同時にノズル から分離して浮上した。その二つの液滴は接触しても一つに 結合することは稀であり、ハイドレート膜の影響と思われる。

(3) 低温海水中 $\mathrm{CO}_{2}$ 液滴単体放出実験

$1 \sim 2$ 分間に一つの液滴を放出することにより、液滴同士 の流体力学的干涉を排除した単一液滴の浮上挙動を調査し た。直径 2～23mm の範囲の液滴が単体で上昇するデータが得 られた。液滴には八イドレート膜が生成している。液滴が大
きいと形状が扁平になり、上半分の方がよりつぶれた上下非 対称になるが、実験の範囲内では周期的な変形や上昇経路の 蛇行はほとんど見られなかった。

\section{3 . $3 \mathrm{CO}_{2}$ 流滴の大きさと浮上速度の解析}

深海の温度 ・圧力条件を模擬した海水中で $\mathrm{CO}_{2}$ 液滴が単 体で浮上する時の、大きさと上昇速度の関係を求める。上述 したように大きい液滴は扁平になるため、レーザ式粒径計測 装置で得られる赤道付近の直径を真球の直径とみなすと、液 滴の体積を過大に評価してしまう。しかしながらレーザ式粒 径計測装置による計測だけでは、液滴の上端・下端付近の測 定精度が悪く、また鈶直方向のスキャンが夜滴の浮上に依存 するという問題がある。そこで以下の手順で解析を行う。

1) $\mathrm{CO}_{2}$ 液滴の水平方向直径の評価 液滴の水平方向直径 $d_{h}$ をレーザ式粒径計測装置による 計測結果から求める。

2 ）液滴形状の把握と鈶直方向直径の算出

ノズルから $2.4 \mathrm{~m}$ 上方で得られたカメラ映像から液滴形 状を把握する。液滴が画面のほぼ中央に来た時の映像を パソコンに取り込み、輝度の閥值を調整して二值化する ことにより、液滴の輪郭を求める（Fig. 5）。液滴の上 昇経路とカメラの前後距離が必ずしも一定でないので、 1 ) で求めた水平方向直径を基準にして大きさの定量化 を行う。液滴を上側と下側で曲率の異なるだ円球により モデル化し、鈶直方向直径 $d_{v}$ を算定する。

3 ) 液滴の体積と等価直径の算出

液滴が軸対称であるとみなし、鈶直軸まわりの積分を行 って、断面形状から液滴の体積を算出する。この体積と 同じ体積を有する真球の直径を求め、これを等価直径 $d_{e q}$ と称することにしてデータ整理に用いる。

4) 浮上速度の評価

液滴が、放川!ノズル近傍の水中カメラの画面中央を通過 してから、 $2.4 \mathrm{~m}$ 上方の水中カメラの画面中央を通過す るまでの時間を求め、上昇時の平均速度を算出して浮上 速度 $u$ として評価する。双方の撮影画像には $1 / 100$ 秒単 位の時刻が同期して写し込まれている。

解析結果の例をFig. 6、7 に示す。Fig. 6 は、ゲージ圧 20MPa、 水温 5.0 度 Cの条件で得られた等価直径と浮上速度の関係を 示すものである。図中、○は実験結果であり、実線は次式で 評価される剛体球の終末速度 $u_{r / 8 / d}$ である。

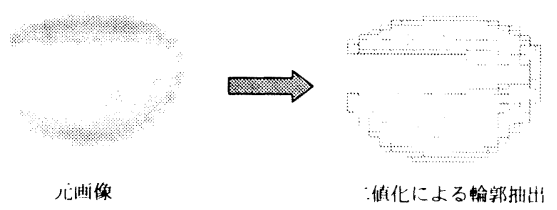

Fig.5 Analysis of picture of $\mathrm{CO}_{2}$ droplet 


$$
u_{r \mid x i d}=\left\{4 d_{c u}\left(\rho_{*}-\rho_{c(\rho) 2}\right) g / 3 C_{D} \rho_{\psi}\right\}^{1 / 2}
$$

ここでの、の $\rho_{(\theta !}$ はそれぞれ周囲海水密度、液化 $\mathrm{CO}_{2}$ 密度で あり、gは重力加速度、 $C_{p}$ は球の抵抗係数で以下のように与 えられる。

$$
\begin{aligned}
C_{D} & =24\left(1+0.125 R_{e}^{0 . i^{2}}\right) / R_{c} & & R_{e}<1,000 \\
& =\left(0.55+48 / R_{e}{ }^{1 / 2}\right)^{2} & & R_{e}>1,000
\end{aligned}
$$

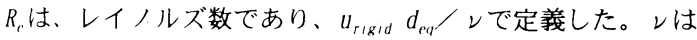
海水の動粘度である。 $\rho_{w} \rho_{c 02}$ およびレは圧力・温度に依 存する。海水については大気圧で測定した密度から塩分濃度 を算川し、いわゆる状態方程式を用いて高圧下の密度に換算 した。○(1)2 およびンはハンドブックう記載の物性值を内挿し て求めた。

また、Fig. 7 は同じ条件における液滴の扁平度 $\left(=d_{v} / d_{h}\right)$ の結果である。等価直径が 8 9m 以下では、液滴はほぼ真 球であり、浮上速度は剛体球に関する従来知見で求められる 計算值と良く一致している。しかし夜滴が大きくなると、液 滴がしだいに扁平していく。剛体球で予想されるよりも浮上 速度は有意に小さくなり、等価直径が $15 \mathrm{~mm}$ 以上では、ばら つきはあるもののほぼ一定值になって、浮上速度が夜滴の大 きさにあまり依存しない傾向が見られる。

\section{3.4 深海桭境下の単一 $\mathrm{CO}_{2}$ 液滴の抵抗係数}

流体中を浮上する物体の終末速度は、物体に作用する余剩 浮力が周辺流体から受ける抵抗力と平衡する条件で推定さ れる。剛体球の終末速度あるいはその推定に無次元值として 与えられる抵抗係数については、古くから実験が行われ、(1) 〜 (3) 式のような推定式が広く知られている。しかしながら、 直径が比較的大きな液滴の場合には、抵抗力による変形や摩 擦に伴う内部流動の影響を受ける可能性がある。これらにつ いても数值解析によって算定する手法の開発が進められて いる (’)が、低温・高圧下の液化 $\mathrm{CO}_{2}$ のように、液滴表面に ハイドレート膜が生成する場合の影響は未知である。

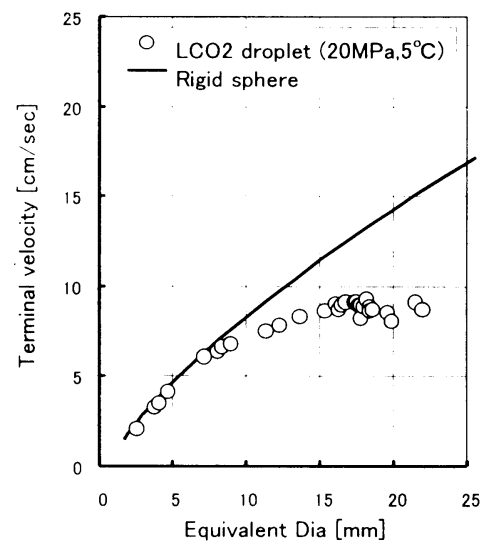

Fig.6 Correlation between terminal velocity and droplet size of $\mathrm{CO}_{2}$
前述したように、本研究では、実際の深海罯境を想定した 温度・圧力・塩分濃度の条件の下で、直径 $2 \sim 23 \mathrm{~mm}$ の液滴を 単体で放出し、浮上速度を直接測定した。その結果にもとづ き、本問題で用いるべき抵抗係数を求めなおした結果が Fig. 8 である。すなわち、抵抗係数 $C_{D C O 2}$ は、実験で得られた 等価直径 $d_{e q}$. 浮上速度 $u$ および海水と $\mathrm{CO}_{2}$ の密度 $\rho_{w}, \rho_{c: 0}$ を用いて次式で求められる。

$$
\begin{aligned}
C_{D}= & \left\{4 / 3 \times \pi \times\left(d_{e q} / 2\right)^{3} \times g \times\left(\rho_{\psi}-\rho_{c 02}\right)\right\} \\
& \nearrow\left\{1 / 2 \times \rho_{w} \times \pi \times\left(d_{e q} / 2\right)^{2} \times u^{2}\right\}
\end{aligned}
$$

Fig. 8 は横軸にレイノルズ数、縦軸に抵抗係数をとって、温 度 2.2〜5.0 度 C、ゲージ圧力 $10 \sim 20 \mathrm{MPa}$ の範囲で得られた 結果をすべてプロットしてある。条件の違いによる実験結果 の差は、同一条件において生じているばらつきのほぼ範囲内 であることがわかる。レイノルズ数が概ね 500 以下では、剛 体球で用いられてきた従来の抵抗倸数曲線（図中破線）とほ ぼ一致してレイノルズ数の増加にともなって単調減少して いるが、 500 以上で抵抗係数が増加に転じている。

そこで、（2）（3）式に変えて、新たな抵抗係数曲線（図中実 線）を次式のように提案する。ただし $R e<1,500$ で適用さ れる。

$$
C_{D C .02}=24\left(1+0.125 R_{e}^{0.75}\right) / R_{c}+R_{e}{ }^{3} / 2.2 \times 10^{9}
$$

\section{3. $\mathrm{CO}_{2}$ 液滴の浮上・浴解挙功シミュレーション}

\section{1 シミュレーション筀手法}

航走船舶による $\mathrm{CO}_{2}$ 中層放流方式において、放流された $\mathrm{CO}_{2}$ 液滴が周囲の海水中に溶解しながら浮上していく挙動 をシミュレーション計算手法 ${ }^{\natural を}$ をいて推定する。

液滴からの溶解速度は、

$$
d\left(\rho_{\mathrm{co} 2} \eta\right) / d t=-k A\left(C_{0}-C_{\infty}\right)
$$

で表すことができ、ここで $\rho_{\mathrm{CO}_{2}}$ は $\mathrm{CO}_{2}$ の密度、V、A は液滴

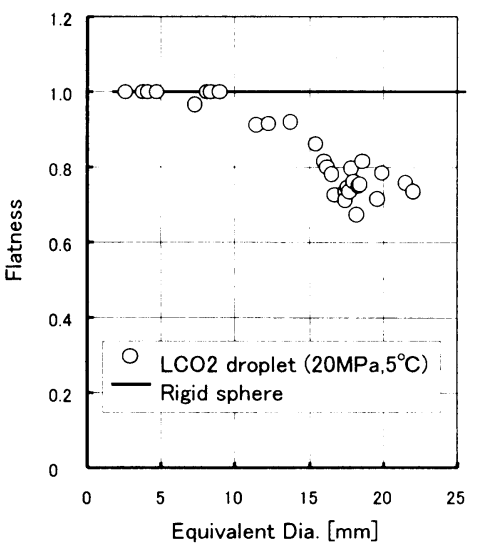

Fig.7 Correlation between flatness and droplet size of $\mathrm{CO}_{2}$ 


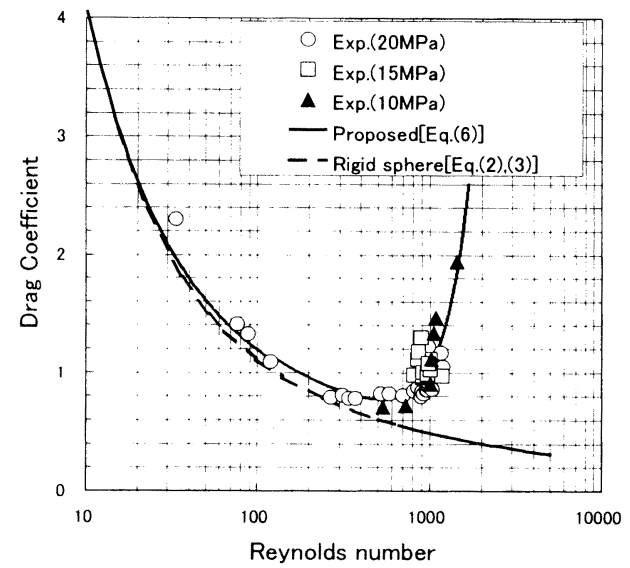

Fig.8 Modification of drag coefficient for $\mathrm{CO}_{2}$ droplet

の体積之表面積、 $C_{j} 、 C_{\infty}$ は液滴表面之無限遠方の $\mathrm{CO}_{2}$ 濃度、 $k$ 㹥質量移動係数である。

ハイドレート膜で覆われた $\mathrm{CO}_{2}$ 液滴表面の $\mathrm{CO}_{2}$ 濃度 $C_{0}$ は、 Hirai ら ${ }^{7)}$ によって実験的に得られており、無限遠方の $\mathrm{CO}_{2}$ 濃度 $C_{\infty}$ はほぼゼロに近い。質量移動係数はシャーウッド数 $S_{h}$ の定義で以下のように用いられている。ただし $d_{e q}$ は液滴 直径、 $D$ は搪散係数である。

$$
S_{h}=k d_{c q} / D
$$

ここで、高圧下での $\mathrm{CO}_{2}$-水系の拡散係数は、ウィルケ・ チャンの式で求められる いる(ただしンは動粘度）と、高シュミット数領域において

$$
S_{h}=1+0.752 R_{e}^{0.472} S_{c}^{1 / 3}
$$

が近似的に成立する ${ }^{9)}$ ので、(7)（8）式を等置すると、新たな 抵抗係数を用いて浮上速度が (1) 式で与えられれば、レイノ ルズ数 $R_{e}$ が定まり、 $k$ が求まることになる。抵抗係数はレイ ノルズ数の関数なので、簪密には綝り返し収束計算が必要で あるが、シミュレーション手法として時刻歴計算を行うとき に、1 ステップ前のレイノルズ数を参照することで現実的に 問題はない。なお（8)式は球体を対象として得られている式 であり、変形の影響は考慮されていない。陸上実験設備では 長い揚程を確保できないので変形による質量移動係数の修 正の必要性については実験的な確認が難しいと思われるが 今後の課題としたい。

\section{2 計算蛣果・考菜}

計算例として、海水および $\mathrm{CO}_{2}$ 液滴の温度は深度によら ず 5 度 $\mathrm{C}$ とし、初期の等価直径が $20 \mathrm{~mm} の \mathrm{CO}_{2}$ 液滴を、深度 $2,000 \mathrm{~m}$ で放流した場合のシミュレーション計算の結果を Fig. 9 に示す。横軸は放流してからの経過時間 (秒)であり、 液滴の位置（深度）、浮上速度、等価直径、ならびに $1 \mathrm{~m}$ 浮 上する間の溶解量について時間变㟟を示している。抵抗係数 としては実験にもとづき新たに得られた(5) 式を用いている
が、参考のために剛体球を仮定した（2）(3)式を用いた場合 の計算結果も併記した。

この計算例から、以下のようなことがわかる。

1) $\mathrm{CO}_{2}$ 液滴は放流されてから溶けきるまでに約 $900 \mathrm{~m}$ 上昇 する。この值は、剛体球を仮定した場合に比べて $15 \%$ ほ ど小さい。

2 ) 液滴が放流されてから溶けきるまでに約 3.5 時間かかっ ている。その間、直径の縮小速度は概ね一定である。

3 ) 液滴の浮上速度は、放流されてから約 2.5 時間の間、ほ ぼ一定である。この間に液滴の等価直径は $20 \mathrm{~mm}$ から $7 \mathrm{~mm}$ 程度にまで減少している。同一の温度・圧力条件では液 滴が小さいほど浮上速度は小さくなるが、浮上して水圧 が減じると $\mathrm{CO}_{2}$ の密度が小さくなり、液滴に作用する 余剩浮力が增えるため、浮上速度の低下を補ったと考え られる。

4) $1 \mathrm{~m}$ 浮上する間に周囲海水に溶け恬す $\mathrm{CO}_{2}$ の量は、放恬 直後が最も多く、浮上しながら液滴の大きさが減るにつ れて隇少する。海洋の自然の㹡散過程を考慮すると、複 数の夜滴は上昇しながら水平方向に散らばっていくの で、周囲海水の $\mathrm{CO}_{2}$ 濃度上昇は、放计点周边で最も大 きくなると言える。今回の計算例では、放流直後に $1 \mathrm{~m}$ 浮上する間に、一個の $\mathrm{CO}_{2}$ 液滴から $0.24 \%$ が溶け出す 結果となった。この值は、剛体球を仮定した場合と比べ て 25\%大きい。

例えば、実機で想定される 1 隻あたりの船から放流される $\mathrm{CO}_{2}$ の総流量 Qを 100 リットル $/ \mathrm{sec}$ 、曳航速度 $v$ を $2.5 \mathrm{~m} / \mathrm{sec}$ とし、曳航パイプから放流される $\mathrm{CO}_{2}$ の横幅 $b$ を小さめに $5 \mathrm{~m}$ と見積もっても、上述の結果を用いると、放流直後に新 たに海水中に溶け込む $\mathrm{CO}_{2}$ の海水に対する重量比は、 $0.0024 Q / v b=1 / 52,000$ と推定される。 $\mathrm{pH}$ 低下に換算す ると約 1 に相当する。この值自身の可否はまだ論じられない が、海洋の自然の希釈に委ねる前に人為的に希釈可能なレベ ルを提示する一例である。

\section{4. 結}

溶解抎散型の $\mathrm{CO}_{2}$ 海洋隔離において、海洋の自然の混合 に委ねる前に人為的に一定以上の希釈度を確保する技術的 方策として、航走船舶による中層希釈放流方式を提案してい る。前報において、水平な軸線を有する流線形のノズルから 放川速度を調整して後乃向きに放流することによって、現実 的な史航速度（4〜 5 ノット）の下で一定以上（直径 $10 \mathrm{~mm}$ 以 上）の液滴形成が可能であるとの見通しを得た。

引き続き本報では、まず、深海の温度・圧力・塩分濃度を 再現した大型高圧容器内の海水中に、液化 $\mathrm{CO}_{2}$ を少量放出 する実験を行い、液滴の浮上形態の観察、ならびに浮上速度 のデータ取得を行った。側壁影響がほとんど無く、鈶直方向 

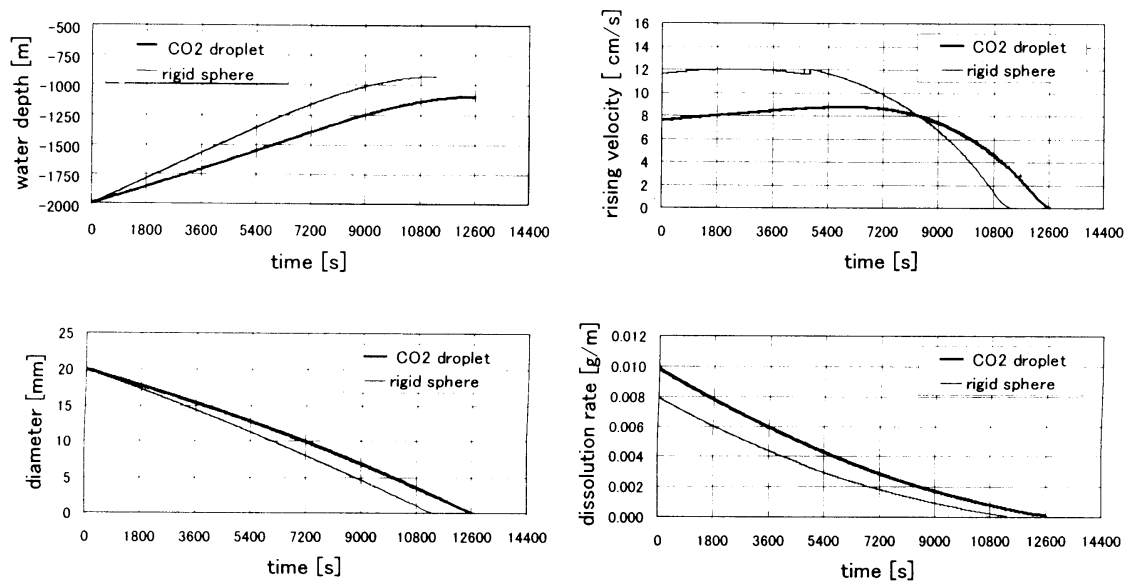

Fig.9 Calculated results of rising and dissolving behavior of $\mathrm{CO}_{2}$ droplet

の距離が大きい容器の中で、実際に液化 $\mathrm{CO}_{2}$ を用いて浮上 挙動を調べた点、ならびに実験中の容器内海水の $\mathrm{CO}_{2}$ 濃度 上昇を極力抑えた実験を行った点に特徴がある。その結果、 液滴表面にハイドレート膜が生成する場合の影響を直接考 慮に入れた、液中液滴浮上挙動を観察し、剛体球に関する従 来知見と比較し、変形にともなう抵抗係数の修正式を新たに 提案した。

次に、実験で得られた抵抗係数を用いて、上昇しながら 徐々に周囲の海水に溶けていく $\mathrm{CO}_{2}$ 液滴の挙動をシミュレ ーション計算で予測した。剛体球を仮定した場合と比べて、 溶けきるまでの浮上距㒕が小さい分、単位長さを浮上する間 に溶け川す $\mathrm{CO}_{2}$ 量が大きめになる点に留意が必要である。 実機想定の100リットル每秒の規模の放流において、放流直 後の最も多い $\mathrm{CO}_{2}$ 溶解量でも海水に対して $1 / 52,000$ の重量 比であるという一計算例を示したが、これは海洋中での自然 による抬散挙動予測、生物影響予測の初期条件として工学的 に可能なひとつの数值であると言える。

\section{謝辞}

大型高圧容器内 $\mathrm{CO}_{2}$ 放出実験を行うにあたり、SAIC 社の Gilbert.R.Stegen 氏ならびにSwRI の Jesse. I. Ramon 氏をは じめとする実験課員には、現地でひとかたならぬお世話にな りました。袋状隔膜を内包する $\mathrm{CO}_{2}$ 容器の製作にあたって は、(財) 電力中央研究所 我孫子研究所の大隅多加志氏をは じめとする関係各位にご指導を賜りました。レーザ式粒径計 測装置の機能増強・調整にあたっては三菱重工業(株) 長崎研 究所の黒田雅博氏ほかのご協力をいただきました。実験装置 の作動確認試験では、三菱重工業(株) 長崎造船所 特殊機械 部の耐圧試験装置を借用しました。多くの関係者の方々にこ の場を借りて謝意を表します。
$\mathrm{CO}_{2}$ 液滴の浮上・溶解挙動シミュレーション計算を行うに あたり、東京工業大学 炭素循環素材研究センターの平井秀 一郎教授より懇切なご指導を賜りました。深謝いたします。

本研究は、新エネルギー・産業技術総合開発機構（NED0） から (財)地球環境産業技術研究機構 (RITE)へ委託された「二 酸化炭素の海洋隔離に伴う環境影響予測技術研究開発」の一 環として行われた。関係各位に篤くお礼申し上げます。

\section{考文献}

1) Herzog, H. et al.: Capturing Greenhouse Gases, Scientific American, Feb. (2000).

2) Ormerod, W.G. et al.: Ocean Storage of $\mathrm{CO}_{2}$, IEA Greenhouse Gas R\&D Programme (1999).

3) Handa, N. and Ohsumi, T. eds: Direct Ocean Disposal of Carbon Dioxide, Terra Scientific Publ. Co., Tokyo (1995).

4）尾崎雅彦ほか: 溶解挔散型 $\mathrm{CO}_{2}$ 海洋隔離における希釈 放流技術に関する基礎研究（その1）、日本造船学会 論文集 第 187 号（2000）。

5) ENCYCLOPEDIE DES GAZ, L'AIR LIQUIDE, ELSEVIER (1976).

6) Sadhal, S. S. et al. : Transport Phenomena with Drops and Bubbles, Springer-Verlag New York, Inc. (1997).

7) Hirai, S. et al.: Dissolution Rate of Liquid $\mathrm{CO}_{2}$ in Pressurized Water Flows and the Effect of Clathrate Films, Energy Vol.22, No.2/3 (1997).

8) Hirai, S. et al.: Measurement of $\mathrm{CO}_{2}$ Diffusion Coefficient and Application of LIF in Pressurized Water, Energy Vol.22, No.2/3 (1997).

9) Clift,R. etal.: Bubbles, Drops and Particles, Academic Press, New York (1978). 